\title{
Notas Sobre la Abogacía en el Mundo Romano
}

Ad D octorem Agerson T abosa Pinto, M agistrum iuris, ex: amicitiae officio et suae sapientiae et magna-nimitatis admiratione.

\section{Modesto Barcia Lago}

Doutor em Direito pela Universidade da Coruña (Espanha). Advogado.

Sumário: I. Un cierto aroma helénico. II. Introducción de la retórica en Roma. III. Oradores y juristas. IV. Etapas de formación del oficio. V. Patronazago liberal y remuneración de la actividad. VI. Reconocimiento del derecho a la remuneración del ejercicio de la Abogacía. VII. Reticencia y crítica social

Resumen: Parte el autor de los orígenes griegos de la oratoria forense romana, que daría lugar a la institucionalización de la profesión de la abogacía a través de una evolución en tres estadios delimitados, del "patronatus iudiciarius", de la actividad liberal y del munus publicum integrado en las corporationes togatorum.

Palabras clave: Roma. Jurista. Abogacía.

\section{I \\ UN CIERTO AROMAHELÉNICO}

Es un lugar común sintetizar la expresión del genio griego en la figura del filósofo y la del romano en la del jurista. Aunque no va descaminada la crítica que, acerca de la preterición del estudio del Derecho griego por la omnipresencia romanista, hacía PALAO HERRERO', podemos, no obstante, asumir la tesis de LATORRE: 
La gran innovación de Roma fue la aparición de un grupo de ciudadanos especializados en estudiar y ayudar a resolver los problemas que planteaban aquellas necesidades sociales. Ellos fueron los juristas. El jurista como figura importante de la comunidad y como persona seriamente dedicada al estudio del Derecho aparece por primera vez en Roma².

Pero las soluciones jurídicas exigen ser actuadas en el proceso ${ }^{3}$ y como apuntaba BARTOL refiriéndose a la diferencia entre las codificaciones griegas y la Ley de las XII Tablas - que tal vez alguna inspiración habrían tenido de Solón el ateniense -, "mientras las leyes griegas son un catálogo de normas, la ley romana es el origen de un sistema jurídico basado en el proceso" y éste no es concebible sin la figura del defensor de la parte, actora o interpelada, concernida por la decisión del arbiter o iudex sobre la quaestio disputata ${ }^{4}$. El officium advocationis pasa, pues, a primer plano si se quiere entender la funcionalidad del sistema jurídico romano, aunque, claro está, se iría perfilando en sucesivas etapas, desde la inicial del patronazgo honorario de los oradores no juristas, hasta alcanzar la fisonomía definitiva de la profesionalidad, prestigio y reconocimiento institucional, que, pese a todas las reticencias de los poderes públicos y aparente descrédito social, conservará durante toda la historia hasta nuestros días, culminando una evolución que entronca con el magisterio de la actividad de los Rhétores judiciales de la Hélade, tan hábiles en la techne peithoús, en el arte de la persuasión, como al propio tiempo, peritos en los dicasterios, syndikoi, y conocedores del nomos ${ }^{5}$ y por ello nomikoi, juristas lato sensu, que ya unían esta condición a la genérica aptitud retórica, tan cultivada por la sofística como denostada por Platón, aun conservando el proceso griego la bipartición en dos fases, la anákrisis y el juicio, que en Roma excusaría, hasta el surgimiento de la cognitio extra ordinem, a los oratores forenses la condición de juristas, apartados éstos en cuanto tales del proceso judicial.

Así que hay que tomar cum grano salis afirmaciones demasiado contundentes acerca de que Grecia nada tenía que enseñar en materia de Derecho y proceso, como sostiene, entre otros, FINLEY, porque, en su opinión, en las poleis, a diferencia de Roma, "nunca se desarrolló una clase de juristas profesionales, de modo que los jurados populares interpretaban la ley a la vez que determinaban los asuntos de hecho, guiados

${ }^{2}$ LATORRE, Ángel: Iniciación a la lectura del Digesto. Editorial Dirosa, en colaboración con el Seminario de Derecho Romano de la Universidad de Barcelona, 1978. Publicación universitaria nº 3; pág. 16.

3 BARTOL, Francisco: La "Lex XII Tabularum ex Cicerone". Revista de Derecho UNED, n 1, 2006; pág. 385.

${ }^{4}$ FUENTESECA DEGENEFFE, Margarita: La función jurisdiccional en Roma. Fundación Registral. Colegio de Registradores de la Propiedad y Mercantiles de España, Madrid, 2008.

5 BARCIA LAGO, Modesto: Abogacía y Ciudadanía. Biografía de la Abogacía Ibérica. Dykinson, S.L. Madrid, 2007. 
solamente por los discursos preparados para las partes por los abogados más o menos profesionales y por citas, dentro de los discursos, de leyes o decretos" ${ }^{\prime \prime}$, pues, en fin, "Atenas no contaba con juristas en el propio sentido del término".

\section{II \\ INTRODUCCIÓN DE LARETÓRICAEN ROMA}

Graecia capta, ferum victorem cepit. Puede ser, como dice LANE FOX, que Roma, "el pueblo más importante del futuro fuera investigado por los primeros seguidores de Alejandro, pero fue el menos comprendido"; ${ }^{8}$ no obstante, el verso horaciano, ya en la época augústea - sintetiza tanto lo que Roma debe a la Hélade, cuanto lo que rebasó de esta herencia, y en el tema que nos atañe, el acervo de la retórica - y muy en concreto la oratoria forense -, iba a convertirse en instrumento fundamental de ascenso económico y social de los homines novi, esos que el historiador de Oxford denomina "advenedizos acaudalados", que nutrían la clase de los potentiores; por más que el viejo Catón y los sectores conservadores del patriciado de la nobilitas clamasen contra la moda de pergraecari, es decir, contra la imitación de los usos y lujos helénicos - que desde el siglo III a.C. deslumbraron a los rústicos hijos de la loba capitolina en Sicilia, el sur de Italia y en el levante mediterráneo -; moda propiciada por el enriquecimiento derivado de la dinámica expansión conquistadora de la República romana y que seducía a la juventud acomodada, poniendo en crisis los valores tradicionales de la austera gravitas y los mores maiorum que conformaran la Ciudad de Rómulo.

Pero no podían ponerse puertas al campo. Pese a las iniciales prohibiciones y hasta expulsiones de maestros helenos, la explosión de entusiasmo helenístico, como cuentan Plutarco o Cicerón, que catalizó aquella famosa embajada del año 155 a.C. donde brilló el académico Carnéades, hizo de la educación retórica y del filohelenismo el referente de los "tiempos modernos" de una República que señoreaba el Mediterráneo sobre las cenizas de su vieja rival Cartago, finalmente destruida el 146 a.C.

Inicialmente cultivada en griego por la juventud acomodada de la nobilitas, que incluso hacía de las estancias de estudios en la propia Grecia marca diferencial de

\footnotetext{
${ }^{6}$ FINLEY, M.I.: El Nacimiento de la Política. Editorial Crítica, S.A. Barcelona, 1986 „pág. 47.

7 FINLEY, Moisés, I.: Vieja y nueva democracia. "Los demagogos atenienses". Ariel, S.A. Barcelona, 1980; pág. 134.

${ }^{8}$ LANE FOX, Robin: El mundo clásico. La epopeya de Grecia y Roma. Crítica, S.L. Barcelona, 2007; pág. 349.

9 Ibídem; pág. 364.
} 
educación superior, ya desde el año 94 a.C. con la iniciativa de Plocio Galo se abrirían escuelas de Retórica en Roma ${ }^{10}$, en las que ésta ya se enseñaba en latín y se hacía accesible a estratos sociales inferiores, al tiempo que se escribirían manuales latinos, como la muy exitosa obra anónima Rethórica ad Herennium, y el ejercicio juvenil De Inventione ciceroniano, ambos con acusadas influencias del tratado de Hermágoras de Temnos y dentro de moldes aristotélicos. El de Arpino cultivaría una retórica forense en sus obras principales, pero, desde el siglo I al V d.C. dominará un escolasticismo desvinculado del compromiso político, como se constata en el "Diálogo sobre los oradores" de Tácito y la práctica va a decantarse en estilismo de las declamationes, como los doce libros de controversiae y los dos de suasoriae de Séneca "el Viejo"; si bien la retórica romana culminaría con la Institutio oratoria del hispano Quintiliano, de neta intención pedagógica de la bene dicendi scientia, que será modelo clásico del Humanismo, dejando definitivamente asentada la vieja definición de Catón "el Censor" del orador como vir bonus dicendi peritus.

\section{III \\ ORADORESYJURISTAS}

Ni que decir tiene que, como ya ocurriera en Grecia, los Tribunales de Justicia de la República fueron lugares privilegiados en donde el dominio del ars oratoria por un patronus confería éxito en la defensa de las causas y fama pública, que podía cimentar un brillante cursus honorum, como fue el caso de Cicerón.

Estos patroni y oratores que actuaban en los procesos defendiendo las posiciones de las partes no eran en las primeras etapas, sin embargo, como pudiera pensarse, juristas, expertos en el ius. El propio Cicerón deja clara la displicencia con la que los oratores, integrantes de un estamento consciente de su fortaleza e influjo social, contemplaban a los cultivadores del ius (De officiis, II, 19), aunque éste no fuese desconocido para él, que tenía presente que el dicere retórico no podía disociarse del sapere - cuanto más amplio, no sólo derecho, mejor y es sobre este fondo que el propio Cicerón reformula la doctrina aristotélica en sus propios Tópica, o en el Brutus y en el "Orator" para expresar el ideal de magister dicendi, vinculado a la práctica del foro - en una profesión práctica como lo era la defensa de los intereses de los particulares.

La jurisprudencia, la ciencia del Derecho, primero ocupación de los Pontífices, pertenecientes al estamento aristocrático de los patricios, era una jurisprudencia "esotérica", "in penetralibus pontificum, isto é, nos santuários dos pontífices", como apunta TABOSA

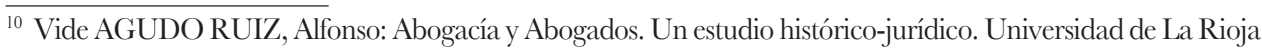
y Egido Editorial. Zaragoza 1997.
} 
PINTO $^{11}$, pero se haría laica y plebeya, desde que, en el año 304 a.C., el liberto Gneo Flavio diese a la publicidad las fórmulas procesales y negociales - el denominado ius flavianum, que el Colegio Pontifical guardaba en secreto -, de manera que, poco después, la lex Ogulnia permitió ya que los plebeyos accediesen a dicho Colegio.

Pues bien, si los responsa prudentium fueron parte principalísima en la creación del monumento del Derecho Romano ${ }^{12}$, sólido cimiento de nuestros sistemas jurídicos, a su lado una pléyade de laudatores, de patroni, y fundamentalmente de oratores, eran quienes en el foro abogaban por los intereses concretos de los ciudadanos cuyo patrocinio asumían. No eran, como se dijo, propiamente expertos conocedores del derecho, sino de la práctica procedimental y de los recursos emotivos de la oratoria, y por eso solicitaban dictámenes y opiniones jurídicas a los iurisprudentes, los intérpretes del ius.

La división de los procedimientos judiciales de las legis actiones y del agere per formulas, que desde el siglo II a.C. fue desplazando el excesivo formalismo y arcaísmo del anterior, en dos fases procesales, la fase denominada in iure y la referida apud iudicem, no hacía necesario el conocimiento jurídico al orator, que practicaba las pruebas de los hechos y realizaba, en defensa de los intereses de su cliente, el alegato público apud iudicem, ante el Tribunal, que estaba compuesto por jueces legos en Derecho, ante los que el patronus exhibía sus dotes oratorias para su persuasión, pero no se ocupaba de las cuestiones específicamente jurídicas; pues en la fase preliminar, la fase in iure, se había ya concretado la pertinente fórmula iuris y el petitum con ayuda del Jurisperito. La labor de estos oratores concernía, así, no al Derecho, reservado al prudens, sino a los hechos, que el jurista minusvaloraba, como lo hacía malhumorado Aquilio Galo: $N$ ihil hoc ad ius, ad Ciceronem! al rechazar consultas sobre cuestiones fácticas, según relata el propio arpinate (Top. 12, 51).

\section{IV \\ ETAPAS DE LAFORMACIÓN DEL OFICIO}

La actividad de la postulatio pro aliis decantará en la advocatio, professio advocationis, dicho con más propiedad, officium advocationis, como dedicación específica del advocatus, término que, por su ajuste semántico, haría fortuna y se generalizaría para designar la figura profesional plenamente reconocida e institucionalizada. Es una evolución que avanzará en tres etapas bien reconocibles al compás de la evolución política y social del mundo romano.

${ }^{11}$ TABOSA PINTO, Agerson: Direito Romano. FA 7-Facultade 7 de septembro; Fortaleza (Brasil), $2^{\mathrm{a}}$ ediçâo, 2003; pág. 59.

${ }^{12}$ DAZA MARTÍNEZ, Jesús/RODRÍGUEZ ENNES, Luis: Instituciones de Derecho civil romano. Jesús Daza, $2^{a}$ edición, Madrid, 1997; pág. 25. 
Se inicia este proceso con lo que cabe denominar patronatus iudiciarius, que, desde una fase primitiva de patronazgo nobiliario estricto, se caracteriza por una relación clientelar entre el patronus y el cliens, carente de cualquier vínculo contractual, en tanto que se asentaba en los deberes de la fides y de la amicitia, y por consiguiente conllevando la gratuidad de los servicios rendidos por el patronus, que revertirían, naturalmente, en su prestigio e influencia social y política, apuntando, eso sí, su condición de orator a miras que excedían la estricta preocupación forense, pues, en el marco de los iura patronatus esperaba contar con agradecimiento de su beneficiado cliente. Pero ello no excluía lo usual de recibir ciertas donationes ex benefficium, que podrían resultar bien remuneratorias, como Cicerón criticaba respecto de Quinto Hortensio, guardándose de su propia fortuna, y cuya creciente desnaturalización en la práctica llevaría a la prohibición establecida en la Lex Cincia de donis et muneribus el año 204 a.G. que, sin embargo, no podría, al cabo, impedir la remuneración de los servicios forenses de los oratores. Culmina esta fase hacia el final de la República.

"Mas o patronato haverìa de acabar, e com ele a advocacia de elite (Brutus, Crassus, Antonius, etc.), a advocacia das arengas elaboradas nas técnicas puramente retóricas, a advocacia exercida sem profesionalismo", dice FRANÇA MADEIRA ${ }^{13}$. La dinámica económico-social de la expansión republicana daba paso a una segunda etapa de desarrollo de una advocatio concebida como dedicación profesional marcada por el interés privado, una etapa ésta "liberal", que cubriría los tiempos del Alto Imperio y transformaría el viejo patronatus iudiciarius en una verdadera proffessio advocationis, que conseguría afianzarse como un honestus labor merecedor de una codigna remuneración, a la par que, paradójicamente, declinaría el prestigio de que gozara el patronazgo republicano mientras se fortalecía la funcionalidad social de la actividad de postulación forense.

A lo largo de esta segunda etapa, en la que, sin perjuicio de significativas oscilaciones terminológicas con que se designaba la actividad y sus practicantes, causidicus, togatus, incluso scholasticus, que, no obstante, denotan matices particulares en su apreciación, se impuso la denominación de advocatus para designar a quienes ejercían la defensa forense de las partes, ya asumiendo la condición de juristas junto a la aptitud elocuente, pero perdiendo el prestigio que incorporaba el antiguo término de orator, ahora reservado para una élite cualificada de modo específico en la retórica de exhibición y desvinculada de la práctica forense. Se distingue con precisión la figura profesional del advocatus respecto de la los jurisconsultos; lo aclaraba el texto de Ulpiano ("Digesto" 3.1.1.2 Ulp. 6 ad.ed.): "Abogar - postulare - es exponer ante el magistrado jurisdiccional la pretensión propia o la de un amigo, o rebatir la pretensión de otro."

${ }^{13}$ FRANÇA MADEIRA, Hélcio Maciel: História da Advocacia. Origens da profissâo de advogado no direito romano. Editora Revista dos Tribunais Ltda. Sâo Paulo-Brasil, 2002; pág. 49. 
Por eso, completaba el matiz en otro apartado ("Digesto" 50.13.1.11 Ulp. 8 de omn.trib.) diciendo: "Debemos considerar abogados a los que se dedican a la defensa de las causas; no se tendrán por abogados, sin embargo, a los que suelen recibir algo por su consulta sin intervenir en las causas."

Así, pues, son diferentes actividades y no pueden confundirse el dictamen y la postulación forense; primariamente, abogar es defender en juicio, disputatio fori.

La denominación de advocatus iría desplazando insensiblemente a la de causidicus, pues este término incorporaba un matiz peyorativo referido al "picapleitos" o simple practicón forense, cuando aquél sumó a su habilidad retórica el conocimiento de la ciencia jurídica. Porque aunque el abogado no pudiese, inicialmente, dar responsa como el jurisconsulto a quien solicitaba dictamen sobre la cuestión a debatir en el foro, no puede sorprender el hecho de que, naturalmente, en su función de defensa iba aneja, inevitablemente, una evaluación de las perspectivas de éxito de la posición del cliente y el consejo o asesoramiento al respecto; como, por lo demás, ya había ocurrido en la Atenas clásica con los logógrafos, que, como expertos juristas, rhétores nomikoi, preparaban los discursos forenses que, desde Solón, las partes declamaban por sí o asistidas de un synégoro, ante los tribunales de jurados populares ${ }^{14}$.

Para el orador forense, el conocimiento del Derecho, si en cualquier caso conveniente, como demuestra el ejemplo ciceroniano y patentiza la propia dinámica profesional, se hizo inexcusable al surgir en la época del Principado el nuevo procedimiento de la cognitio extra ordinem, que iría apartando al formular.

En efecto, el nuevo proceso extraordinario operaba la refundición en una sola fase procesal de las dos, in iure y apud iudicem, de que constaban los procesos anteriores y ya no era posible disociar el argumento jurídico de la exposición fáctica. Tanto más, cuanto que se iba a acentuar la burocratización del aparato judicial imperial encomendado a jueces funcionarios y no a legos como en época republicana ${ }^{15}$. El advocatus resumiendo en su figura los antiguos papeles del patronus y del orator,añadió, en consecuencia, la condición de iuris peritus, ejerciendo, así, los tres cometidos clásicos del agere, respondere y cavere. De forma que, andando el tiempo la abogacía iba incorporar a su primaria función oratoria, también la dimensión jurisconsulta.

Y lo haría configurando ya definitivamente el concepto del oficio con otras dos notas peculiares que deben destacarse: a) la independencia y libertad de criterio profesional del abogado; particularidad contra la que van a estrellarse todas las

\footnotetext{
${ }^{14}$ BARCIA LAGO, Modesto: Abogacía y ciudadanía. Biografía de la Abogacía ibérica. Editorial Dykinson, S.L. Madrid, 2007.

${ }^{15}$ FERNÁNDEZ DE BJUJÁN, Antonio: Derecho Público Romano. Recepción, Jurisdicción y Arbitraje. Editorial aranzadi, S.A. Navarra, $9^{a}$ edición, 2006; pág. 501.
} 
tentativas de control externo de su actividad, de una parte, y b) la exclusividad de su ministerio, es decir, el monopolio profesional de su cometido, de otra.

Así, respecto de la primera característica, un texto de Paulo (D.3, 3,77) proclama: "Todo el que es defendido debe serlo al arbitrio de buen varón."

Respecto de la segunda, pronto quedó claro(D. 3.1.1 Pr. Ulp. 6, ad ed.), que solamente quienes estuviesen autorizados podrían abogar: "El pretor estableció este título para hacer valer su decoro y velar por su dignidad, evitando que abogase ante él un cualquiera."

El trabajo del advocatus, pues, como ha estudiado con su habitual rigor RODRÍGUEZ ENNES ${ }^{16}$, se diferenciaba netamente de otras profesiones de menor rango social, como el pragmaticus, el leguleius y el formularius, dedicaciones todas que cumplían cometidos complementarios o auxiliares de la labor de aquél.

El tiempo del Bajo Imperio contempla el devenir de la tercera fase evolutiva, caracterizada por una reglamentación intensa y creciente del oficio y su estructuración corporativa en los ordines advocatorum derivada de la envoltura burocrática del Poder público, que concibe la abogacía como un munus publicum que le resulta ya imprescindible y que, paralelamente, se muestra preocupado por la conveniente formación jurídica y moral de los oficiantes, dando lugar a la creación de las escuelas, demandadas ya por los aspirantes, pues el prestigio que fue alcanzando el oficio hizo surgir la práctica de la "pasantía" de los jóvenes, que deseosos de iniciarse en los secretos del foro, seguían a sus maestros en el Tirocinium fori y en las Stationes ius publice docentium aut respondentium, y, después de la división del Imperio, se formarían en las prestigiosas Escuelas de Beirut y de Constantinopla, entre otras de menor importancia, así como la constitución Omnem reipublicae contiene el plan de estudios de Justiniano ${ }^{17}$.

Pero, pese a la cuasi funcionarización de los abogados, defenderían éstos su independencia profesional incardinándola en la conciencia de servicio público, si es que esta expresión anacrónica nos es permitida, transformando, ya para siempre, la profesión en un ministerio público ejercido con autonomía por profesionales particulares, sin perjuicio de las oscilaciones que la tensión entre la base privada y la función pública de la profesión introducía en la sempiterna reticencia con que desde el Poder se contemplaba la indisciplinada libertad de abogar y los sucesivos intentos de control e intervención administrativa de la misma.

\footnotetext{
${ }^{16}$ RODRÍGUEZ ENNES, Luis: La remuneración de la oratoria forense: del rechazo inicial a su aceptación social y normativa. Contribución publicada en Studi in memoria di Giambattista Pallomeni; publicazioni della Facolta di Giurisprudenza della Universita di Trieste, núm.44. Milano-Dott. A. Giufre Editore, 1999.

${ }^{17}$ GARCía GARRIDO, Manuel Jesús/EUGENIO, Francisco: Estudios de Derecho y Formación de Juristas. Editorial Dykinson, S.L. Madrid, 1990.
} 


\title{
PATRONAZGO LIBERAL Y REMUNERACIÓN DE LAACTIVIDAD
}

Importa destacar que el patronazgo patricio tenía inicialmente el carácter de un mecenazgo protector del inmigrante peregrino, que así se convertía en cliente, protegido, de un civis romanus persona de relieve e influencia social. La prestación de protección a su cliente era un ars liberalis, ejercido gratuitamente por el patronus como carga - onus - inexcusable de su condición patricia, por lo que no podía ser actividad mercenaria; aunque, obviamente, su desarrollo en el foro daba ocasión al patronus para el lucimiento, que le reportaba consideración social - honos - e influencia política; la relación clientelar venia definida por el conjunto de los iura patronatus - una especie de estatuto de vasallaje - que, entre otras servidumbres y gabelas, iba acompañado del abono de una retribución no exigible - el honorarium -, por contraposición a la retribución ordinaria del salarium, propia de las operae o artes illiberales, preservándose así el carácter de gratuidad característico de las artes ingenuae, vinculadas al concepto de amicitia, derivado de la noción aristotélica de filia, ese "ser otro yo mismo" que glosaba LLEDÓ comentando la expresión del autor de la "Ética eudemia" (VII, 30) y que Cicerón recoge diciendo (De Amicitia VII,23) que verum enim amicum qui intuetur, tanquam exemplar aliquod intuetur sui.

Esta relación desigual y vasallática entre el patrono y su cliente la define Plutarco con precisión:

\begin{abstract}
...pero aun se distinguió de otro modo a los principales respecto de ésta (la plebe), llamándolos patronos, esto es, protectores; y a los plebeyos, clientes, como dependientes o colonos, estableciendo al mismo tiempo entre unos y otros una admirable benevolencia, fecunda en recíprocos beneficios; porque aquéllos se constituían abogados y protectores de éstos en sus pleitos, y sus consejeros y tutores en todos los negocios; y éstos los reverenciaban, no sólo tributándoles obsequio, sino dotando a las hijas de los que venían a menos y pagaban sus deudas; y a atestiguar no se obligaba, ni por ley ni por los magistrados, o al patrono contra el cliente o al cliente contra el patrono. Ahora, últimamente, con quedar las mismas obligaciones de unos y otros, se ha considerado ignominioso y torpe el que los poderosos reciban retribución pecuniaria de los clientes ${ }^{19}$.
\end{abstract}

Sin embargo, otra vez de modo semejante a lo que ya había ocurrido en Atenas con los logógrafos y los synégoros, no podía mantenerse la gratuidad de los servicios jurídicos, cuando el notable incremento de la litigiosidad, propiciada por el desarrollo

\footnotetext{
${ }^{18}$ LLEDÓ, Emilio: Memoria de la Ética. Santillana, S.A. Taurus, Madrid, 1994; pág. 108.

${ }^{19}$ PLUTARCO: Vidas paralelas. Cicerón, En Biógrafos Griegos; pág, 911.
} 
económico y social, planteaba la necesidad de satisfacer la creciente demanda de servicios forenses; demanda social reforzada por la extensión, cada vez mayor, hasta hacerse general con el Edicto de Caracalla, del 212 d.C., que solamente excluyó de ella a los dediticii, rebeldes a la autoridad de Roma, del estatuto de ciudadanía ${ }^{20}$ y por el enriquecimiento y ascenso social de un gran número de oficiantes, advocati, causidici y otros relacionados, la mayoría de extracción social plebeya y carentes de otros recursos propios que no fueran los obtenidos con su dedicación profesional, que se integraban en la categoría de homines novi - clase de la que Cicerón sería el paradigma - surgidos al calor del desarrollo y que ejercían una influencia social y política notable.

En estas circunstancias, aunque la lex Cincia de donis et muneribus, del año 204 a.C., en tiempos republicanos, lo había prohibido expresamente, se imponía la costumbre, como quedó dicho más atrás, de percibir una remuneración habitual por la prestación de tales servicios forenses, bien que fuese disfrazada de gratificación no mercenaria.

Aunque, obviamente, no todos tenían la misma fortuna, como refiere Marcial en sus epigramas (Epigr. XII, 72; IV, 46), lo mismo que Juvenal (Saturae VII, 119), el oficio podía ser bien remunerador y así lo acredita Tacito el historiador en un "Diálogo sobre los oradores", destacando, en una tertulia de abogados prestigiosos, como dos de los más famosos, Eprio Marcelo y Crispo Vibio, habían logrado un patrimonio personal de doscientos y trescientos millones de sestercios, respectivamente, "por la gratificación a su elocuencia", y subraya la baja extracción social de tales oradores, para resaltar la importancia de este arte, diciendo:

\begin{abstract}
Cuanto más humilde e ínfimo fue su nacimiento y cuanto más notable fue la pobreza y lo precario de la situación que los rodeó al nacer, tanto más ilustres son sus ejemplos para demostrar la utilidad de la oratoria, porque sin apoyo en su linaje, sin fortuna que los respalde, sin sobresalir ninguno de los dos por sus hábitos y nada favorecido uno de ellos por su aspecto físico, son durante muchos años ya los más influyentes de la ciudad y, mientras quisieron, los príncipes del foro, y ahora son los primeros en la amistad del César, tienen todo en sus manos y son apreciados por el mismo príncipe con un especial respeto, porque Vespasiano, anciano venerable y que no se ofende nunca con la verdad, se dio perfecta cuenta de que, mientras sus restantes amigos se apoyaban en lo que habían recibido de él mismo y en lo que estaba dispuesto a acumular en ellos mismos o destinar a otros, Marcelo y Crispo habían aportado con su amistad lo que no habían recibido, ni podía serlo del Príncipe.
\end{abstract}

Y por eso, concluía su alegato: "Podemos ver cargados de honores, distinciones y riquezas las casas de quienes, desde el comienzo de su juventud, se entregaron a las causas forenses y a su afición por la oratoria' ${ }^{21}$.

\footnotetext{
${ }^{20}$ Para el proceso de incorporación de los hispanos a la ciudadanía romana, véase la magnífica monografía de BRAVO BOSCH, Mª José: El largo camino de los hispani hacia la ciudadanía. Dykinson, S.L. Madrid, 2008.

${ }^{21}$ TACITO: Diálogo sobre los oradores, 8,3 y 4.
} 
Es así, que el parejo incremento de la influencia de los abogados plebeyos, signo del ascenso social de los homines novi cual lo era Cicerón, se dobla con las tensiones sociales y políticas que recorren la tardo República - cuya historia secreta, como dijera Carlos Marx, radica en la propiedad de la tierra - y el Imperio.

El hispano Marco Valerio Marcial, cuyo talento literario se ofendía con la ordinariez de las ínfulas poéticas de Flaco, le recomendaba con desprecio que se dedicase por entero al oficio forense, diciéndole que "el foro de Roma está más cerca y es más rico; allí suena el dinero", dejando caer, de paso, la inmoralidad que lo animaba, de modo que las personas honestas no tenían lugar en Roma y solamente, "si eres bueno, puedes vivir, Sexto, de milagro"22, aunque también reconocía los beneficios de la profesionalidad (Epigr.I, 17).

El mismo Tacito da cuenta en los "Anales", del disgusto con que los sectores aristocráticos soportaban el dinamismo profesional que enriquecía y ennoblecía a un estamento plebeyo, cuya dedicación al oficio de abogar lo era con todo descaro mediante la contrapartida de crecidas retribuciones, en contravención pública de la antigua Lex Cincia caída en desuso. El propio historiador se complace en la percepción aristocrática, según la cual, "por entonces no había mercancía más venal que la perfidia de los abogados" ${ }^{23}$ y Ovidio descargaría la rabia de su decepción amorosa con un símil acaído, del mismo modo era indecoroso ofrecer amores mercenarios que era deshonesto defender a los miserables con lengua comprada: turpe, reos empta miseros defendere lingua ("Amores" I, 10, 35).

\section{VI \\ RECONOCIMIENTO DEL DERECHO ALAREMUNERACIÓN DEL EJERCICIO DE LAABOGACÍA}

La tensión había estallado con ocasión del suicidio de un insigne caballero romano, Samio, al que un afamado y amoral abogado de extracción social plebeya, Suilio, le había cobrado cuatrocientos mil sestercios y se planteó por ello la revalidación de la vieja prohibición del ejercicio forense mercenario; prohibición, como sabemos, ligada al carácter patricio de la actividad de los oratores.

Sobre la base de su propia potencia económica, las clases aristocráticas terratenientes argumentaban, por boca del Cónsul Gayo Silio, la nobleza del patrocinio como ars ingenua, porque en los viejos tiempos de las relaciones regidas por los iura -patronatus se había "considerado la fama y la gloria en la posteridad como premio

\footnotetext{
${ }^{22}$ MARCIAL: epigramas, 1,76 .

${ }^{23}$ TACITO, Cornelio: Anales. Libro XI, 5.
} 
de la elocuencia", pues de otra manera, "la más hermosa y la principal de las artes liberales quedaba mancillada por sórdidas mercaderías" ${ }^{24}$.

Por eso, un auténtico "Príncipe del Foro" como Cicerón, según cuenta Plutarco, reprochaba a su colega Quinto Hortensio que percibiese retribución por sus defensas, ya que la actividad del orador forense solamente perseguiría procurar un beneficium, y consiguientemente, habría de ejercerse gratuitamente a favor de la colectividad; aunque no dejaba de ser un reproche un tanto hipócrita, pues el propio preclaro orador no desdeñaba, por su parte, aceptar valiosos donativos por sus defensas, que le procuraban un saneado patrimonio.

Pero, lo cierto es que los conservadores optimates, a los que tanto cuidaba Cicerón, asumían esta posición y así el inquisitivo Cónsul Gayo Silio arguía fogoso en su alegato contra Suilio y los otros, que, "si los pleitos no se hacían en provecho de nadie, habría menos", mientras que el afán de lucro de los advocati era altamente pernicioso, porque con él se favorecían las enemistades, las acusaciones, los odios y las injusticias, de manera que, al igual que la virulencia de las enfermedades proporciona ganancias a los médicos, así también la podredumbre del foro les suponía dinero a los $\mathrm{Abogados}^{25}$.

Es decir, para los críticos patricios del oficio, los abogados, cual carroñeros, se alimentaban de las miserias de la sociedad, si es que no eran ellos mismos quienes provocaban la existencia de los pleitos para lucrarse a cuenta de los incautos que acudían a recabar sus pérfidos servicios; no serían, pues, las discrepancias y contradicción de intereses entre los ciudadanos en una sociedad dinámica, las que hacían nacer la abundante conflictividad, cuya resolución en términos jurídicos aquéllos profesionales del foro canalizaban ante los tribunales desde la perspectiva que convenía, claro está, a sus clientes.

$\mathrm{N}$ ihil novum sub sole. Es ésta una recriminación que se repetirá constantemente a lo largo de la historia y llega a nuestros días.

Sin embargo, ello no dejaba de ser el velo ideológico que ocultaba la ambición reaccionaria de volver a las antiguas costumbres del clientelismo servil de los estamentos plebeyos en favor de las clases patricias. Como apuntaba Mesala en el citado "Diálogo" tacitiano, una oratoria profesional, aprendida en las escuelas de retórica, que buscaba el efecto demagógico antes que el beneficium público, era una corrupción de la verdadera ars oratoria practicada por los antiguos y, en realidad, en su opinión, resultaba contraproducente para el buen orden social:

\footnotetext{
${ }^{24}$ TACITO: Anales, Libro XI, 6.
}

${ }^{25}$ Ibídem. 


\begin{abstract}
Pues bien, hubiera sido mejor no tener motivos de queja que reclamar justicia. Porque si pudiera lograrse una ciudad en la que nadie cometiera faltas, superfluo resultaría el orador entre inocentes, lo mismo que un médico entre gente sana; igual que el arte del médico no encuentra posibilidad de práctica y perfeccionamiento entre personas que disfrutan de una salud robusta y de unos cuerpos sanos, en el mismo grado es menor el prestigio de los oradores y más oscura su gloria entre gentes de buena conducta y bien dispuesta para obedecer a sus gobernantes. ¿Qué necesidad tiene el senado de largos debates cuando los optimates llegan a un rápido acuerdo?:Qué necesidad de continuas peroratas en la asamblea del pueblo cuando en las deliberaciones no participa la masa ignorante, sino un caudillo de enorme categoría? ¿Qué necesidad de acusaciones particulares, cuando se delinque tan escasa y levemente? ¿Qué necesidad de defensas odiosas y abusivas, cuando la clemencia del juez acude en ayuda de los acusados? ${ }^{26}$
\end{abstract}

Reverberan en este debate ecos antiguos, pero lo que nos atañe en esta polémica romana sobre la profesionalización retribuida de los abogados, es destacar el argumento con que Suilio, Cosuciano y los demás imputados por cobrar por su patrocinio honorarios crecidos, desvirtuando la primitiva liberalidad patricia inherente a esa dedicación, defendían animosamente la licitud de la remuneración de sus servicios; en su opinión, en realidad, los cobros por una dedicación que les suponía el esfuerzo de estudio constante y el abandono de sus asuntos particulares para atender los ajenos, no eran otra cosa que los emolumenta pacis; ésto es, la condigna retribución de un trabajo útil en una sociedad de ciudadanos libres.

Porque, ¿de qué servirían las leyes sin el abogado que las hiciese valer ante el Tribunal? Quintiliano, el famoso orador y maestro de oratoria hispano, respondería sentencioso: "El hecho es que las mismas leyes no tendrían valor alguno si no estuviesen defendidas por la voz idónea del abogado".

Pues, en definitiva, destacaban en su defensa Suilio y Cosuciano, con su actividad profesional, "lo que se hacía era proporcionar un apoyo a la necesidad práctica, de manera que nadie se encontrara a merced de los poderosos por falta de abogados" - argumento que hará suyo el Rey Alfonso X el Sabio en "las Partidas" (III, título VI, preámbulo) y que ya había esgrimido el rhétor Hipérides en sus brillantes piezas retóricas forenses en la Atenas del siglo IV a.C. ("Defensa de Licofrón", 10; "Defensa de Euxenipo", XXV, 11) -, al mismo tiempo que un modo legítimo de ascenso social de los plebeyos "que resplandecían en la abogacía", y que carecían de las grandes fortunas que les facilitaran, como a los famosos Asinio, Mesala, Esernio o Arruncio, que sus detractores ponían de ejemplo de nobleza y gloria oratoria, "haber adoptado un aire magnánimo" de liberalidad, ya fuese por volver colmados de riquezas y honores alcanzados en botines y rapiñas de guerra, o bien por haber heredado patrimonios cuantiosos.

\footnotetext{
${ }^{24}$ TACITO: Diálogo sobre los oradores, 41,3 y 4.
} 
Pero los abogados, militantes profesionales, en fin, de la causa de la convivencia cívica, "no eran más que unos modestos senadores que en una república tranquila no buscaban más que las recompensas propias de la paz"27.

El desenlace se decantó por la licitud del cobro remuneratorio y, cierto que un tanto a regañadientes, el Emperador Claudio aceptó el derecho a percibir retribución, aunque rebajó la crecida minuta, reduciéndola a diez mil sestercios, que en lo sucesivo serviría de parámetro de la licita quantitas. Se habría de consolidar la legitimidad plena de la percepción de retribución por los servicios forenses, en los avatares de un camino que pasaría por Nerón, quien, pese al recrudecimiento del antiguo rigor de la vieja Lex Cincia en su tiempo, llega, no obstante, a reconocer el derecho de los abogados a una certa et iusta merces y se llegaría a tomar la referencia de un cierto valor de mercado; incluso Trajano ya admitirá el cobro de percepciones anticipadas, provisiones de fondos que garantizaban el cobro a clientes reacios como ya criticaba Marcial ("Epigr." I, 98), en un incidente protagonizado por el abogado Nominato; aunque el derecho de retribución de los abogados, como otros productos y servicios en el contexto de crisis social y económica del Imperio, sufriría las limitaciones del Edictum de pretiis rerum de Diocleciano, y por fin se articulará la exigibilidad procesal del pago a través del procedimiento de la cognitio extra ordinem ${ }^{28}$.

De manera que el ejercicio remunerado de la Abogacía se convertiría, como constata Quintiliano en su "institución oratoria", al fin en un honestus labor, preguntándose el calahorrense quae iustior adquirendi ratio quam ex honestisimo labore, por estimar que la defensa forense era el modo más digno de ganarse la vida (Inst. orat.12).

Así se desprende ya de la tesis que Tacito pone en boca de Marco Apro, uno de los contertulios de su mencionado "Diálogo sobre los oradores", reprochando a su ilustre compañero de oratoria forense Curiacio Materno, el preferir "las salas de lectura y los teatros al foro y los pleitos, a las auténticas luchas"29, evadiéndose de las "fatigas del foro" ${ }^{30}$ y de la notoriedad e influencia pública que esta profesión reportaba por solazarse en el diletantismo poético.

\footnotetext{
${ }^{27}$ TACITO: Anales, XI, 11, 7.

${ }^{28}$ Cfr. Alfonso AGUDO RUIZ: Abogacía y Abogados. Un estudio histórico-jurídico. Universidad de La Rioja y Egido Editorial; Logroño-Zaragoza, 1997.

${ }^{29}$ TACITO: Diálogo sobre los oradores, 10, 5.

${ }^{30}$ Ibidem, 11,3.
} 


\section{VII \\ RETICENCIAY CRÍTICA SOCIAL}

No extraña que, al quebrar el corsé patricio y constituirse el ejercicio de la Abogacía como oficio profesional remunerativo, abierto al estamento plebeyo, si la vieja ars oratoria se ensalzaba, en palabras de Cicerón, reclamando la preeminencia de la toga sobre la milicia y recabando para ella los laureles de la gloria cívica - cedant armae, togae; concedant laurea, laudi (De Officiis I,XXII,77) -, suscitase la figura del abogado una gran desconfianza, e incluso hostilidad y animadversión, caracterizándosele, desde entonces para toda la posteridad, como personaje codicioso, favorecedor de la querulancia, cínico, inmoral, jactancioso y engañador de quienes a él acudían incautamente en busca de consejo o defensa jurídica, experto en retorcer la ley para su propio provecho y beneficio, en vez de colaborar a la realización de la justicia.

Pero era cierto que, cuando la actividad del patrocinio forense rompió el marco patricio, en el que la liberalidad, gratuidad del servicio, venía a ser elemento esencial de una relación asimétrica de vasallaje entre el patrono y su cliente, y se hizo lucida y remunerativa, el incontrolado afán de lucro se convirtió en polo de atracción de un sin fin de pícaros, cuya venalidad y codicia, no atemperadas por la solvencia de conocimientos, ni por la virtud cívica del servicio público, dio ocasión a la lógica desconfianza hacia un oficio que, se presentaba afeado por la perversión de muchos de sus practicantes, suscitando la recriminación social e institucional. Y si Juvenal reconocía (Saturae, XVI, 47) lentaque fori pugnamus arena, criticando los privilegios forenses militares, porque ciertamente los ciudadanos corrientes luchan "en la arena viscosa del foro", en donde el tribunal no está menos empapado de las pasiones de los litigantes que el circo lo estaba de la sangre de los gladiadores, los literatos, como el propio Juvenal, Lucilio o Marcial, no se anduvieron con remilgos en la sátira y crítica destemplada de los malos usos del oficio, aunque, muchas veces, resultasen aquellas sarcásticas descalificaciones más expresión de su incomodo particular que objetivas invectivas contra las disfunciones del foro, como puede advertirse en el disgusto de Apuleyo contra la "locuacidad mercenaria" ("Apología", 3) que le difamaba.

No debe extrañar la reticencia oficial y el intento de encorsetar con normativa casuística la labor de los abogados. Su independencia profesional, si pronto sirvió a muchos oficiantes, claro, de cobertura de actitudes indignas, no puede agradar, en general, a los rectores de la cosa pública. De ahí que se dictase un corpus normativo regulador de su intervención forense y de control de sus retribuciones, prohibiéndose el pacto de quota litis, que el Digesto califica de malus mos, tildándolo el calahorrense Quintiliano de piraticus mos, considerándose ilícita la costumbre de vincular el éxito de la acción al cobro de honorarios subidos - el palmarium - y descalificándose con severidad al abogado que incurría en esa práctica denominándolo avarus et avidus aeris. Criterios deontológicos estas 
prohibiciones de la quota litis y del palmarium, que han llegado hasta nuestros días, en que el viento neoliberal de la "desregulación" los ha barrido, con dudosa ventaja, por cierto, para los ciudadanos que utilizan esos servicios profesionales.

Pero ya se sabe por el refrán que, "hecha la ley, hecha la trampa", y como habría de recoger el dicho popular español, "da elocuencia al abogado el dinero ya contado". Las limitaciones al tiempo de exposición de los oratores, medido por la clepsidra, un reloj de agua ya empleado en Grecia, no impedía rellenar el líquido consumido de aquélla, cuando la indolencia del juez lo consentía, o el interés del discurso así lo requería; lo que la experiencia del vulgo enseguida tradujo como parejo aumento de los honorarios del profesional, en la expresión malévolamente intencionada de "dar más agua al abogado" con el propósito de estimular su eficaz facundia; pues, según el testimonio de Tacito en su "Diálogo" comentado, "en nuestros tiempos, el juez se adelanta al que está hablando y, si no queda convencido y seducido por el desarrollo de los argumentos, o por el colorido de las sentencias, o por el brillo y cuidado de las descripciones, le vuelve la espalda"31, acuciándose, de este modo, en los profesionales una preparación en la elocuencia, pero también en la desfachatez de ataques a personajes renombrados, ya que el público estimaba la osadía y "hasta los comediantes se servían de los gustos del pueblo"32. Ello fácilmente degeneraba en detrimento del fondo de justicia de los argumentos, según la queja de Mesala, y Salustio observa que canina, ut ait Appius, facundia exercebatur, es decir, "se practicaba, como afirma Apio, una elocuencia malhumorada" "Fragmentos de Historia" 4, 54).

Quintiliano exhortaba a guardar "el mayor cuidado posible al hablar en público" para servir con diligencia a la causa que el abogado ha de defender consejo que haría suyo el Rey Alfonso X el Sabio cuando en "Las Partidas" ordenaba que el abogado "debe fablar ante el juez mansamente, e en buena manera, e non a grandes bozes, nin tan baxo que non lo puedan oyr" (Partida III, título VI, ley VII). Aunque Plinio el Joven era de la opinión de que "la primera virtud de la que un juez debe responder ante su conciencia es la paciencia, que constituye uno de los elementos fundamentales de la justicia" y por eso se mostraba generoso concediendo el máximo de clepsidras, aunque era consciente de que, en ocasiones, podría ser un tiempo de mera divagación, diciendo que "lo admito sin más, pero es preferible que se digan cosas superfluas a que no se digan las necesarias", y recomendaba, con imágenes de experiencia campesina, que en el alegato judicial se sembrase esparciendo semillas sobre un vasto terreno para recoger lo que germinase, porque, a fin de cuentas, "las disposiciones de los jueces son tan imprevisibles, inciertas y engañosas como las del tiempo y del terreno ${ }^{33}$.

\footnotetext{
${ }^{31}$ TACITO: Diálogo sobre los oradores, 20, 2.

${ }^{32}$ Ibidem, 40.

${ }^{33}$ PLINIO el Joven: Cartas, I, 20 (a Cornelio Tacito).
} 
Igualmente, también se reveló harto difícil la erradicación de los malos mores en la percepción de las retribuciones y otros abusos y distorsiones, a que la complicidad de las codicias de los propios clientes, cuando no la corrupción de los encargados de impartir justicia, daba ocasión y estímulo.

Así, no cejarían los Poderes Públicos de intentar el control y sometimiento de la actividad y de las retribuciones de los abogados, siempre antipáticos por su independencia, por otra parte, timbre de grandeza del oficio, frecuentemente incomprendido en su verdadera significación de muralla defensiva de la ciudad.

Por eso, más allá de los motivos personales y hasta mezquinos de muchos de los denuestos de la opinión pública oficial o del "parnasso", pues ya se sabe que, de acuerdo con el refrán gallego, "cada quén fala da feira segundo lle foi nela", lo importante de esta crítica social que vehicula la literatura satírica, y que retomará con brillantez el sarcasmo de la novela picaresca y del teatro de "de cordel" del siglo de oro ibérico, es la madurez interna que demuestra, pues asume ya los matices profesionales expuestos por Cicerón en De Officiis, distinguiendo los cometidos del juez y del abogado como piezas de un sistema que busca realizar el Derecho como ars boni et aequi, en la bella expresión de Celso; de manera que, para el eximio orator romano (De Officiis, II, 14,51 ), iudicis est semper in causis verum sequi; patroni nonnumquam verisimile, etiam si minus sit verum, defendere; es decir, si en todo caso el juez debe perseguir la verdad, al abogado incumbe defender lo verosímil, aunque a fin de cuentas no sea toda la verdad, sino la parte de ella que interesa al derecho del cliente, ya que, de otro modo, si como dice el adagio, de veritate magis quam de victoria, solliciti esse debent causarum patroni, si los defensores de las causas debieran perseguir la verdad más que la victoria, se estaría confundiendo - como le sucedía a Platón en su crítica a los sofistas, pero también puede advertirse en la desconfianza del formalismo escriturario egipcio contra la oratoria forense, como cuenta Diod. Sículo ("Bibl. Hist." I, 76, 2)-, el proceso judicial, contradictorio, con juegos florales de jurisprudencia a cuenta de los intereses de los litigantes; una tentación que se repetirá a lo largo de la historia entre quienes preferirían no tener que confrontar en términos de debate de derecho las decisiones del Poder, sino solamente vestirlas con el adorno de la apariencia.

Por eso la crítica se dirige contra las desviaciones respecto del canon de comportamiento decoroso y ético que en la vida personal y profesional de sus oficiantes se producen, incluso contra la propia querulancia de los particulares (Marcial: "Epigr. VII, 65; VIII, 9)) y no contra la profesión en sí misma, cuyo prestigio social acrecentaban afamados forenses, según lo fueron, además de Cicerón, notabilísimos jurisconsultos, entre los cuales destacaban Numa, calificado de "oráculo de la jurisprudencia", Licinio Craso, Quinto Mucius Scaevola, Celso, Papiniano, o Herennio Modestino - el último jurista clásico - , y entre los que desempeñaron con nombre propio también distinguidas damas. Así, cabe recordar a Mesia Sentina, de la que cuenta elogiosamente Valerio Máximo que mereció por su competencia y coraje el sobrenombre de "Andrógina", 
ya que "escondía un alma viril en su aspecto de mujer"; igualmente descollaron con luz autónoma Amasia y Hortensia; pero, debido a las quejas que provocaba el descaro e impudor con que Caya Afrania se comportaba ante los tribunales, se prohibió que las mujeres ejerciesen oficios "viriles"; disposición que habría de retomar Alfonso X el Sabio en "Las Partidas" y estaría vigente prácticamente hasta poco más de un lustro antes de los tiempos de la Segunda República española y no comenzaría a normalizarse la presencia de las féminas en los oficios jurídicos y otras profesiones que antes les estaban vedadas, hasta mediada la época del franquismo, para hacerse torrente incontenible desde la instauración de la Democracia ${ }^{34}$. Brasil sería en este tema la Nación adelantada del mundo ibérico, al admitir, ya en 1902, a Doña María Augusta Saraiva como primera mujer abogado, en lo que fue seguido por Portugal, que, en 1913, autorizó, a despecho de las normas prohibitivas entonces existentes, a Doña Regina Quintanilha a "exercer o patrocínio em pleito que decorreu no Tribunal da Boa-Hora"35. Pero el Pais Lusitano fue el primero de la iberidad ${ }^{36}$ que contó con una mujer Bastonário al frente de la Orden dos Advogados Portugueses, Doña María de Jesús B.L.M. Serra Lópes, que desempeñó esta responsabilidad en el período 1990-1992 y en la novísima Orden dos Advogados de Cavo Verde, ejerció de Bastonario Doña Lígia Arcângela Lubrino días Fonseca en 2001. El cargo homólogo en España, el de Presidente del Consejo General de la Abogacía Española, Corporación institucional de la profesión que agrupa a los diferentes Colegios de Abogados territoriales, todavía no ha sido ocupado por una mujer, si bien la Decana del Ilustre Colegio de Abogados de Tenerife, Doña Carmen Pitti García, fue la primera que sentó plaza de Vicepresidente en tal Consejo.

La conciencia que los profesionales tenían de su propia estima y nobleza del oficio, llevaría, desde el siglo III a formar agrupaciones, que darían lugar, en el marco cortesano del Bajo Imperio, al primer Collegium T ogatorum, de preceptiva incorporación para todos, presidido por el Primus fori, a quien correspondían importantes privilegios y honores de Spectabilis y Clarisimus, máxima dignidad atribuida a los senadores y cónsules.

${ }^{34}$ Para una panorámica de la profesionalidad jurídica de la mujer en España Véase YANES PÉREZ, José Santiago: Mujer y Abogacía: Biografía de María Ascensión Chirivella Marín; Ilustre Colegio de Abogados de Valencia, 1998. Para la etapa central del franquismo en España, véase el documentado estudio de ESPUNY TOMAS, María Jesús/CANABATE PEREZ, Josep/ GARCIA GONZALEZ, Guillermo/ PAZ TORRES, Olga: Subiendo al estrado: Mujeres y Administración de Justicia (19611966). En JAIME DE PABLOS, Ma Elena (Ed.): Identidades femeninas en un mundo plural. 2009 Arcibel editores http://www.arcibel.es.

${ }^{35}$ ALVES, Adalberto: História Breve da Advocacia em Portugal. Ediçâo do Clube do Coleccionador dos Correios, 2003; pág. 156.

${ }^{36}$ Acerca de este concepto, véase BARCIA LAGO, Modesto: Geopolítica de la Iberidad. Dykinson, S.L. Madrid, 2008. 
De esta manera, la corporación de los abogados se constituye en un auténtico cursus honorum, puesto que in advocatorum tutela, non privatorum duntaxat, sed et reipublicae salus continetur, no solamente se les confía la protección de los intereses de los particulares, sino la propia salvación del Estado. y, en definitiva, resulta proporcionado el elogio de que nec solos militare credimos, illos, qui gladiis nituritur; sed etiam advocatos: militant namque a causarum patroni, qui gloriosae vocis confisi munimine, laborantium spem, vital et posteros defendunt; ya que, desde luego, no sólo se milita con la espada, sino que los abogados, verdaderos militantes de la convivencia cívica, con su discurso defienden la esperanza, la vida y la posteridad de los desafortunados, como de manera, tal vez hiperbólica, pero atinada en la dirección de fondo, decía el "colorido elogio" con que la Constitución del año 443 (C.J. 2, 7, 14 "Impp. Leo et Anthemius AA. Callicatri P.P. Illyrici" se refiere a los Abogados. Un tono laudatorio que, junto con las críticas, se convertirá en recurrente.

Pero aquí debo poner fin a estas notas de humilde, pero sentido, homenaje al eminente jurista y universitario que es el Prof. Dr. Agerson Tabosa Pinto, a quien, desde este lado del Océano Atlántico que susurra amoroso en la ría de Pontevedra, en el recuncho gallego de España, mirando para Brasil al Occidente, rindo tributo de amicitia.

\section{REFERENCIAS}

AGUDO RUIZ, Alfonso. Abogacía y Abogados. Un estudio histórico-jurídico. Zaragoza, Universidad de La Rioja y Egido Editorial. 1997.

ALVES, Adalberto. História Breve da Advocacia em Portugal. Edição do Clube do Coleccionador dos Correios, 2003.

BARTOL, Francisco. La “LexXII Tabularum ex Cicerone”. Revista de Derecho UNED, n 1, 2006.

BARCIA LAGO, Modesto. Abogacía y ciudadanía. Biografía de la Abogacía ibérica. Editorial Dykinson, S.L. Madrid, 2007.

BRAVO BOSCH, Ma José. El largocaminodelos hispani haciala ciudadanía. Dykinson, S.L. Madrid, 2008.

DAZA MARTÍNEZ, Jesús/RODRÍGUEZ ENNES, Luis. Instituciones de Derecho civil romano. Jesús Daza, 2a edición, Madrid, 1997.

ESPUNY TOMAS, María Jesús/CANABATE PEREZ, Josep/ GARCIA GONZALEZ, Guillermo/ PAZ TORRES, Olga. Subiendo al estrado: Mujeres y Administración de Justicia (1961-1966). En JAIME DE PABLOS, Ma Elena (Ed.): Identidades femeninas en un mundo plural. 2009 Arcibel editores http://www.arcibel.es. 
FINLEY, Moisés, I. Vieja y nueva democracia. "Los demagogos atenienses". Ariel, S.A. Barcelona, 1980.

El Nacimiento de la Política. Editorial Crítica, S.A. Barcelona, 1986.

FERnÁnDEZ DE BJUJÁN, Antonio. Derecho Público Romano. Recepción, Jurisdicción y Arbitraje Editorial aranzadi, S.A. Navarra, 9ª edición, 2006.

FRANÇA MADEIRA, Hélcio Maciel. História da Advocacia. Origens da profissão de advogado no direito romano. Editora Revista dos Tribunais Ltda. Sâo Paulo-Brasil, 2002.

FUENTESECA DEGENEFFE, Margarita. La función jurisdiccional en Roma. Fundación Registral. Colegio de Registradores de la Propiedad y Mercantiles de España, Madrid, 2008.

GARCÍA GARRIDO, Manuel Jesús/EUGENIO, Francisco, Estudios deDerecho y Formación de Juristas. Editorial Dykinson, S.L. Madrid, 1990.

LANE FOX, Robin. EI mundo clásico. La epopeya de Grecia y Roma. Crítica, S.L. Barcelona, 2007.

LATORRE, Ángel. Iniciación a la lectura del Digesto. Editorial Dirosa, en colaboración con el Seminario de Derecho Romano de la Universidad de Barcelona, 1978. Publicación universitaria n 3.

LLEDÓ, Emilio. Memoria de la Ética. Santillana, S.A. Taurus, Madrid, 1994.

PALAO HERRERO, Juan. El sistema jurídico ático clásico. Dykinson, S.L. Madrid, 2007.

RODRÍGUEZ ENNES, Luis. La remuneración de la oratoria forense: del rechazo inicial a su aceptación social y normativa. Contribución publicada en Studi in memoria di Giambattista Pallomeni; publicazioni della Facolta di Giurisprudenza della Universita di Trieste, núm.44. Milano-Dott. A. Giufre Editore, 1999.

TABOSA PINTO, Agerson. Direito Romano. FA 7-Facultade 7 de septembro; Fortaleza (Brasil), $2^{a}$ ediçâo, 2003.

YANES PÉREZ, José Santiago. Mujer y Abogacía: Biografía de María Ascensión

Chirivella Marín. Ilustre Colegio de Abogados de Valencia, 1998. 


\section{REFERENCIADE FUENTESANTIGUAS}

APULEYO:

Apología

CICERÓN:

De Officiis; De Amicitia; Brutus; Topica; De Inventione retorica, Orator.

DIODORO SÍCULO:

Biblioteca Histórica

HIPERIDES:

Defensa de Licofrón; En defensa de Euxenipo

HORACIO:

Epístolas; Sátiras

JUVENAL:

Sátiras

MARCIAL:

Epigramas.

OVIDIO NASON:

Amores

PLINIO el Joven:

Cartas.

PLUTARCO:

Vidas paralelas. Cicerón.

QUINTILIANO:

Institución Oratoria

SALUSTIO:

Fragmentos de Historia

TACITO, Cornelio:

Anales; Diálogo sobre los oradores

VALERIO MÁXIMO:

Dichos y Hechos memorables 
478 Temas de D ir eit o Privado

\section{FUENTESNORMATIVAS}

ALFONSO X el Sabio:

Las Partidas

JUSTINIANO:

Digesto

Código

\section{NOTASSOBRE AADVOCACIANO MUNDO ROMANO}

Resumo: O presente artigo aborda o início das origens gregas da oratória forense romana, resultando na institucionalização da profissão da advocacia, através da evolução em três estágios delimitados: o patronatus iudiciarius, a atividade liberal e o munus publicum, integrado nas corporationes togatorum.

Palavras-chave: Advocatus. 0 rator. Patronus. Officium advocationis. 